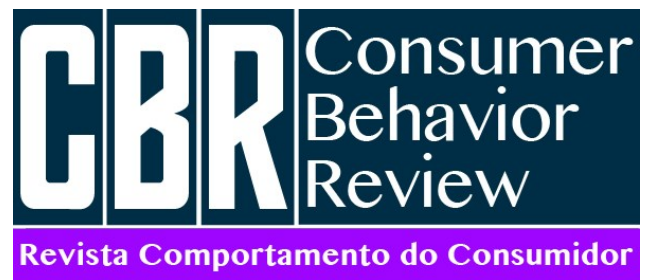

Nzowa, S. (2021). Customer Switching Intentions in Commercial Banks: A case of selected commercial banks in Dar es Salaam. Consumer Behavior Review, 5(3), 307320.

DOI: https://doi.org/10.51359/2526-7884.2021.250399

ISSN: 2526-7884

Editor: Prof. Dr. Marconi Freitas da Costa

E-mail: cbr@ufpe.br
Evaluation: Double blind review

Received: May 4, 2021

Approved: July 15, 2021

\title{
CUSTOMER SWITCHING INTENTIONS IN COMMERCIAL BANKS: A CASE OF SELECTED COMMERCIAL BANKS IN DAR ES SALAAM
}

\author{
Intenções de Troca do Cliente em Bancos Comerciais: Um caso de bancos comerciais selecionados \\ em Dar es Salaam
}

\author{
Seule Nzowa ${ }^{1}$ \\ ORCID: http://orcid.org/0000-0002-4022-5883 \\ E-mail: mtajesi@gmail.com \\ ${ }^{1}$ Institute of Rural Development Planning, Dodoma, Tanzania
}

\begin{abstract}
The negative consequences of customer switching behaviour in the banking industry cannot be underestimated. Since there are limited studies addressing customer switching intentions and actual switching behaviour in the banking sector of Tanzania, this study intended to bridge the knowledge gap by addressing factors influencing customer switching intentions in the context of Tanzanian commercial banks. The study followed a positivism research paradigm out of which a deductive research approach was adopted. In the same line, an explanatory research design was used. The study was conducted in the city of Dar es Salaam with 400 respondents who were customers from NMB Bank Plc, TPB Bank Plc and NBC Bank Ltd. Multi-stage sampling method was used to generate sample size for this study. Multiple
\end{abstract}

\begin{abstract}
Resumo
As consequências negativas do comportamento de mudança de cliente no setor bancário não podem ser subestimadas. Uma vez que existem estudos limitados sobre as intenções de troca do cliente e o comportamento de troca real no setor bancário da Tanzânia, este estudo pretendeu preencher a lacuna de conhecimento ao abordar os fatores que influenciam as intenções de troca do cliente no contexto dos bancos comerciais da Tanzânia. 0 estudo seguiu um paradigma de pesquisa positivismo, a partir do qual uma abordagem de pesquisa dedutiva foi adotada. Na mesma linha, foi utilizado um desenho de pesquisa explicativo. 0 estudo foi conduzido na cidade de Dar es Salaam com 400 entrevistados que eram clientes do NMB Bank Plc, TPB Bank Plc e NBC Bank Ltd. $O$ método de amostragem em
\end{abstract}


linear regression was employed to analyze the collected data. The findings of Thé study indicated that subjective norms were insignificant in influencing customer switching intentions in commercial banks. These findings suggested that commercial banks customers in the city of Dar es Salaam are not under robust social pressure that requires a vital social group to approve their switching intentions. Further findings revealed that perceived control of bank charges, attitude toward service quality and convenience significantly influenced customer switching intentions in commercial banks.

Keywords: Bank charges; Service quality; Subjective norms; Convenience. múltiplos estágios foi usado para gerar o tamanho da amostra para este estudo. A regressão linear múltipla foi empregada para analisar os dados coletados. Os resultados do estudo indicaram que as normas subjetivas foram insignificantes para influenciar as intenções de troca do cliente em bancos comerciais. Essas descobertas sugerem que os clientes dos bancos comerciais na cidade de Dar es Salaam não estão sob forte pressão social que exige que um grupo social vital aprove suas intenções de troca. Outras descobertas revelaram que o controle percebido das despesas bancárias, a atitude em relação à qualidade do serviço e a conveniência influenciaram significativamente as intenções de troca de clientes em bancos comerciais.

Palavras-chave: Taxas bancárias; Qualidade de serviço; Normas subjetivas; Conveniência.

This work is licensed under a Creative Commons Attribution 4.0 International License.

\section{INTRODUCTION}

It should be noted that customer switching from bank to bank in the banking industry is a universal phenomenon. This has been taking place worldwide. Ernst \& Young (2011) reported that in 2009 about $36 \%$ of bank customers worldwide shifted from their original banks to other banks and $7 \%$ of the customers were planning to shift to other banks. Accordingly, in 2012, it was revealed that the proposition of customers who were planning to switch from one bank to another had increased from 7\% to 12\% since 2011 (Ernst \& Young, 2012). The World Retail Banking Report (WRBR, 2018) pointed out that, banks are facing a threat of losing their customers as $32.3 \%$ of customers were likely to switch from their service banks to other banks with more attractive customer services and operating environments.

In Europe, it was reported that a substantial number of bank customers have changed from their original banks at some point in their life (Ernst \& Young 2010). Statistics in the United Kingdom (UK) shows that 1.16 million banks' customers switched from their original banking services to other banks in 2014 (statista.com). It was also noted in 2019 that approximately 1 million bank customers shifted from their initial banking services to other banks. In 2019, it was estimated that about 2.8 million adult Australians change their banking relationships every year (Deloitte access economics, 2019). In the United States of America (USA), 11\% of bank customers have shifted from their primary banks to other banks in 2016 (Accenture, 2017).

In South Africa, customer switching from one bank to another increased from 34\% in 2011 to 39\% in 2012 (Ernst \& Young, 2012). Accordingly, in 2017 it was established that 83\% of South African bank customers indicated their intentions to switch from their primary banks to other banks (BSG, 2017). Similar challenges were reported in Zimbabwe by Munatsi and Zhuwau (2019) with an average of nine (9) per cent of bank customers intending to switch between the years 2014 and 2016. However, in 2017, customer switching intention in bank business increased to 11 per cent and stood at 21 per cent in 2018. In the context of Tanzania, customer tendency to switch bank is associated with the reforms in the financial sector introduced in the 1990s. The reforms resulted in the establishment of many banks where commercial banks constitute the largest proportion of all banks in Tanzania (Ally, 2013). According to the BoT report (2019), there were 39 fully licensed commercial banks in Tanzania. 
The banking industry in the country comprises both local and international banks operating under high competition. This competition has increased customer choices and has paved room for customer consideration to switch between banks. In many cases, customer switching intentions lead to actual switching behaviour. Consequently, customer switching behaviour, particularly customer switching out has negative effects on business operations as it results to loss of revenue, lower profit margins as well as an increase of operational costs and the cost of obtaining new customers (Keaveney \& Parthasarathy, 2001; Murungu, 2013).

Therefore, if this issue is not properly and adequately addressed, banks will continue to experience customer shifting and losses. Examples, in Tanzanian commercial banks, it was reported that the number of customers at NMB Bank PLC had decreased from 1,803,000 in 2011 to 1, 778,000 in 2013 (NMB Bank PLC Annual report, 2015). Conversely, the number of customers increased from 1,778,000 in 2013 to 2,710, 000 customers in 2017 (NMB Bank PLC Annual report, 2017). This implies that NMB bank Plc has been experiencing customer switching out and in over time. Officers at the NBC bank LTD Tanzania, point out that there is a high rate of customer switching out to other banks (Murungu, 2013). However, it was revealed that quality of service, price and stiff competition were the factors behind the high rate of customer switching out in a particular bank (ibid.). Yet, from the past three years TPB bank Plc indicated an increase of 430,589 customers and some of them were customers from other banks to TPB bank Plc (TPB bank Plc Strategic Plan Office, 2018).

However, empirical literature on factors influencing customer switching intentions in commercial banks are still minimal in the Tanzanian context and African continent in general even though commercial banks of African countries have been experiencing customer switching intentions and actual switching behaviour. Additionally, previous attempted studies on factors influencing customer switching in commercial banks of Tanzania have not dealt out with the problem in depth. For instance, Mkoma (2014) and Millas (2013) addressed customer switching in the banking industry based on customers' satisfaction. Thus, it was, therefore, essential to systematically assess the influence of perceived control of bank charges, attitude toward service quality, subjective norms and convenience on customer switching intentions in commercial banks of Tanzania. Generally, this study assessed factors influencing customer switching intentions in commercial banks.

\section{THEORETICAL REVIEW}

This study was guided by the theory of planned behaviour (Ajzen, 1991). The theory was propagated to predict an individual's intention to engage in behaviour at a specific time and place. It asserts that individuals' behaviours are driven by behavioural intention which is a function of an individual attitude toward behavior, subjective norms and perceived behaviour control. Thus, the core factor under this theory is individual intention to perform a particular behaviour.

However, as it comes to switching intentions in marketing perspective; the construct of perceived behaviour control has been related to the concept of price by Pande and Soodan (2015). Also, the concept of perceived behaviour control has been associated with switching cost (Hasbullah, Mahajar \& Salleh, 2014; Lee, Murphy \& Swilley, 2007; Caruana, 2007 and Bansal \& Taylor, 2002) and in this study; it was associated with perceived control of bank charges.

Accordingly, individual attitude behaviour has been connected to service quality (Gronross, 1998; Morgan \& Dev, 1994 and Bolton \& Drew , 1991). According to Farah (2017), subjective norms are social pressures enforced by important individuals, such as family members, peers, and colleagues at work. However, subjective norms have been related to customer beliefs and perceptions (Taylor \& Todd, 1995). Such norms tend to affect the decision of an individual to be involved in certain behaviour (Ruefenacht et al, 2015).

Bansal and Taylor (1999) noted that numeral variables addressing behaviour in the service industry are not utilized by the TPB. Thus, it has been advocated for future studies to have additional variables to the particular theory. Convenience has been recognized as a variable under the Service Switching Model proposed by Keaveney (1995). Evidence from prior studies pointed out that customers are more likely to switch from one service provider to another based on matters related to convenience (Nimako, 2012; Gerrard \& Cunningham, 2004 and WRBR, 2018). The mentioned cases 
demonstrate the significance of convenience on customer switching intentions in service businesses. Hence, the construct of convenience was merged with TPB to assess factors influencing customer switching intentions in commercial banks of Tanzanian context.

\section{EMPIRICAL LITERATURE REVIEW}

\section{Perceived control of bank charges and Customer Switching Intentions}

Vaitone and Skackauskiene (2020) highlighted that a customer tends to change service provider when the service charge is high. Zakiy (2019) established that price had significant influence on customer intention to switch from one bank to another. The evidence presented by Agarwal (2019) thus far supports that bank charges had significant influence on customer switching intention in the Indian banking industry. In support of the influence of perceived control of bank charges on customer switching intentions in commercial banks, price (bank charges) had been shown to induce customer switching positively (Ceesay, 2017). Therefore, based on these cases, the first hypothesis of this study was:

H1: Perceived control of bank charges have a significant influence on customer switching intentions in commercial banks

\section{Attitude toward Service quality and Customer Switching Intentions in Commercial Banks}

Service quality was generally seen as a factor that strongly influences customer switching behaviour (Suryawardani \& Wulandari 2020). Similar findings have been seen in the case of Chukwuemeka and Godswill (2017) who noted that service quality significantly drive switching intention among bank customers. A case reported by Elliot (2019) also supports the view that customers are more likely to choose who to bank with based on service that best value for them. This context provided the basis for the next hypothesis of the study:

H2: Attitude toward service quality has a significant influence on customer switching intentions in commercial banks

\section{Subjective Norms and Customer Switching Intentions in Commercial Banks}

The research findings reported by Gall and Olsson (2012) established that subjective norms significantly influence customer switching intentions in retail banking. Accordingly, the construct of subjective norms was found to be significant in influencing customer switching intentions in the banking industry of Spain (Farah, 2017). Tai and Chuang (2016) suggested that subjective norms were an important variable in predicting customer switching intentions in the banking business. Sivakumaran and Peter (2020) concluded that subjective norms were a factor motivating bank customers to shift from their primary banks. Thus, this study aimed to test whether subjective norms influence customer switching intentions in commercial banks.

H3: Subjective norms have a significant influence on customer switching intention in commerce banks

\section{Convenience and Customer Switching Intentions in Commercial Banks}

Bansal and Manjit (2019) reported that convenience was one among the variables influencing customer switching intentions in India. Accordingly, Nimako (2012) stressed that customers are more likely to stop complaining to bank service providers where the problem is one of judgment associated with bank service pricing or charges and convenience in accessing the services. Bugyei (2019) suggested that bank location had a significant relationship with customer switching behaviour in Ghana's banking industry. Based on the stated arguments, another hypothesis of this study was:

H4: Convenience has a significant influence on customer switching intentions in commercial banks 


\section{CONCEPTUAL FRAMEWORK}

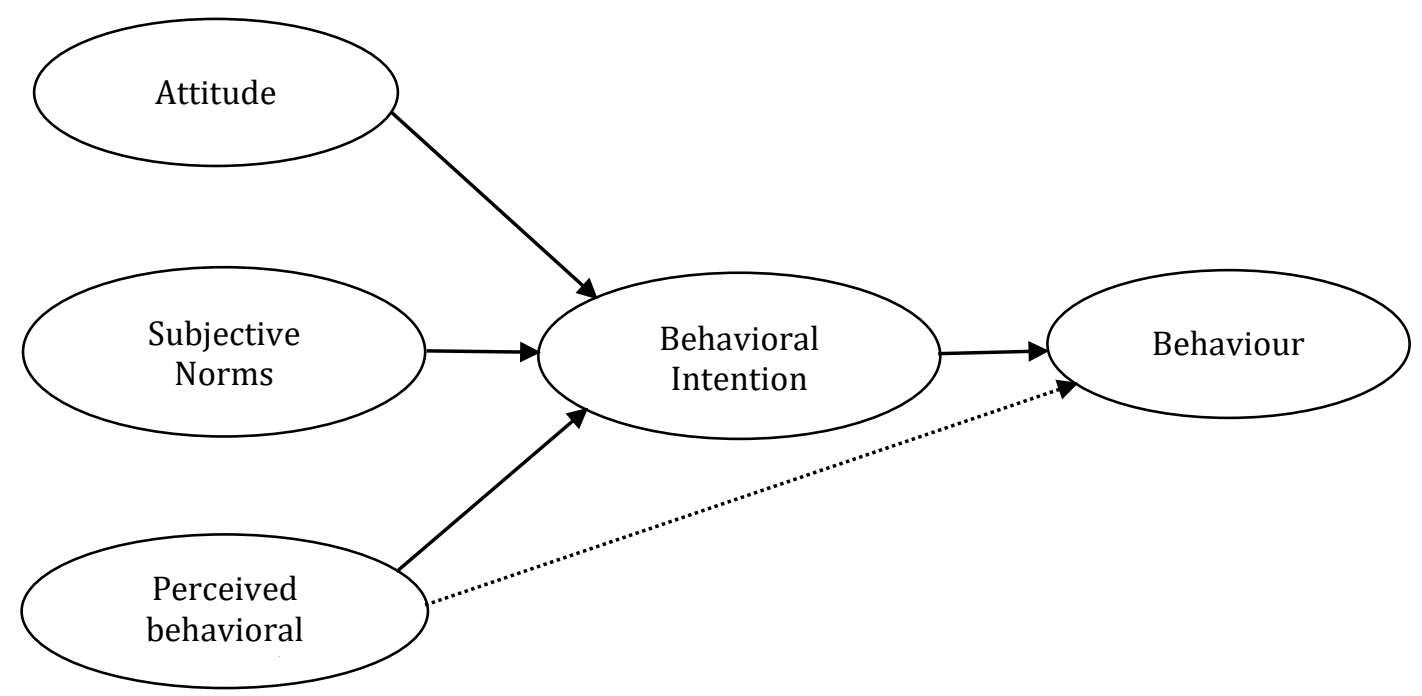

Figure 1. Theory of Planned Behaviour (Ajzen, 1991)

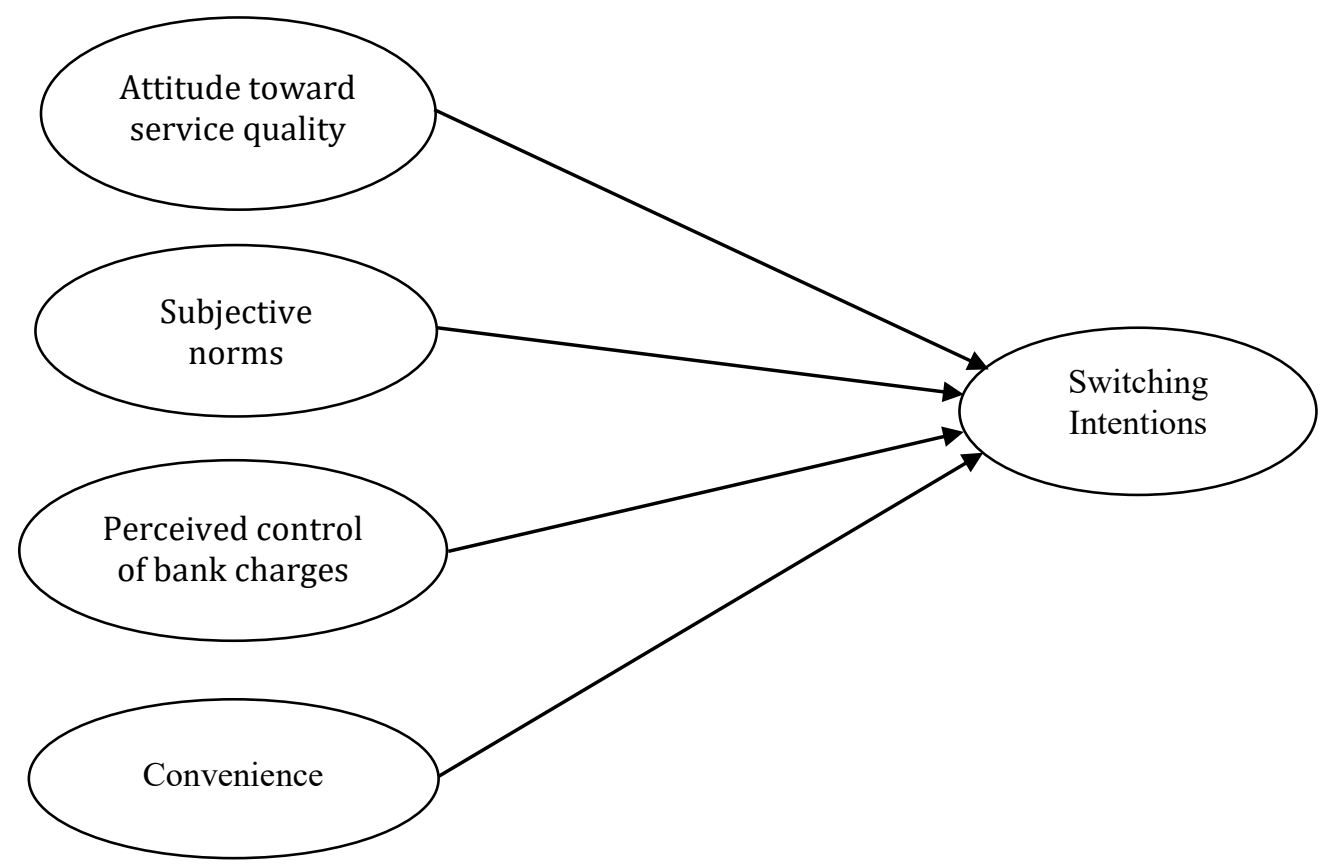

Figure 2. Conceptual Framework (Modified by the researcher, 2021)

\section{METHOD}

The study was conducted in the city of Dar es Salaam with 400 respondents who were customers from NMB Bank Plc, TPB Bank Plc and NBC Bank Ltd. Multi-stage sampling method was used to generate sample size for this study while a close-ended questionnaire was used to collect data. Multiple linear regressions were employed to analyze the collected data. 


\section{Measurement of variables}

In this study, variables on the factors influencing customer switching intentions were measured as follows; perceived control of bank charges were measured by using a multidimensional scale adapted from Chung and Petrick (2015); attitude toward service quality was measured by using a multi-item scale (SERVQUAL) adapted from Parasuraman, Zeithaml and Berry (1985) subjective norms were measured by using a multi-item scale adapted from Gall and Olsson (2012) and Keaveney's (1995) multi-item scale was adapted to measure variables of convenience and customer switching intentions. Variable on switching intentions was measured by using a multi-item scale adapted from Anton, Camerero and Carrero (2007). A bipolar scale of 7 points was used to summarize the scores of the independent variables and dependent variable in the study.

Table 1

Measurement of Variables and Scale Used

\begin{tabular}{|c|c|c|c|}
\hline Variables & Items & Scale & $\begin{array}{l}\text { Other authors } \\
\text { who used the } \\
\text { scale }\end{array}$ \\
\hline $\begin{array}{l}\text { Perceived control of } \\
\text { bank charges }\end{array}$ & $\begin{array}{l}\text { 1.Withdraw charges } \\
\text { 2. Level of interest rate on a loan } \\
\text { 3. Transaction costs } \\
\text { 4. Costs of maintaining accounts } \\
\text { 5. Fair charges to customers }\end{array}$ & $\begin{array}{l}\text { Multidimension } \\
\text { al scale }\end{array}$ & $\begin{array}{l}\text { Chung and Petrick } \\
\text { (2015) }\end{array}$ \\
\hline $\begin{array}{l}\text { Attitude toward } \\
\text { service quality }\end{array}$ & $\begin{array}{l}\text { 1. Assurance of keeping a customer's } \\
\text { records } \\
\text { 2.Reliability of bank staff to address } \\
\text { customer complaints } \\
\text { 3. Knowledge base and customer caring } \\
\text { etiquette of bank staff } \\
\text { 4.Effectiveness of communication from } \\
\text { the bank employees } \\
\text { 5. Responsiveness of a bank to } \\
\text { customer's feedback } \\
\text { 6. Assurance of bank staff to address a } \\
\text { customer's problem }\end{array}$ & $\begin{array}{l}\text { A multi-item } \\
\text { scale } \\
\text { (SERVQUAL) }\end{array}$ & $\begin{array}{l}\text { Parasuraman, } \\
\text { Zeithaml and Berry } \\
\text { (1985) }\end{array}$ \\
\hline Subjective norms & $\begin{array}{l}\text { 1.People who influence customer } \\
\text { behaviour } \\
\text { 2.People who are important in the } \\
\text { customer's life } \\
\text { 3. Switching from current bank to a new } \\
\text { bank would be a good idea } \\
\text { 4. Friends and family } \\
5 \text { Many customers are impressed by my } \\
\text { bank's operations }\end{array}$ & $\begin{array}{l}\text { A multi-item } \\
\text { scale }\end{array}$ & $\begin{array}{l}\text { Gall and Olsson } \\
(2012)\end{array}$ \\
\hline Convenience & $\begin{array}{l}\text { 1. Accessibility of the bank } \\
\text { 2.Speed of services delivery } \\
\text { 3.Easiness of transaction } \\
\text { 4. Bank hours of services } \\
\text { 5.Technology and equipment deployed } \\
\text { by a bank }\end{array}$ & $\begin{array}{l}\text { A multi-item } \\
\text { scale }\end{array}$ & Keaveney (1995) \\
\hline $\begin{array}{l}\text { Customer switching } \\
\text { intentions in } \\
\text { commercial banks }\end{array}$ & $\begin{array}{l}\text { 1.Likelihood } \\
\text { 2.Intention }\end{array}$ & $\begin{array}{l}\text { A multi-item } \\
\text { scale }\end{array}$ & $\begin{array}{l}\text { Anton et al. (2007), } \\
\text { Jones et al. (2007) } \\
\text { and Murad (2011). }\end{array}$ \\
\hline
\end{tabular}




\section{FINDINGS OF THE STUDY \\ Convergent Validity}

In this study, convergent validity was examined by using the Average Variance Extracted (AVE). Hair et al. (2010) pointed out that convergent validity can be accepted when the standardized factor loading is 0.5 or above. Churchill (1979) highlighted that the values of regression weights must range between 0.5 and 0.7 for convergent validity to be accepted. Based on the approach developed by Fornell and Lacker (1981); convergent validity can be attained when the value of AVE for each construct is above 0.5. The findings of this research revealed that the value of AVE for each variable was above 0.5 . This implies that the study met the criteria of convergent validity. The summary of the results is indicated in Table 2

Table 2

Average Variance Extracted and Maximum Shared Variance

\begin{tabular}{l|l|l}
\hline & AVE & MSV \\
\hline Perceived control of bank charges & 0.783 & 0.183 \\
\hline Attitude toward service quality & 0.585 & 0.256 \\
\hline Subjective norms & 0.533 & 0.341 \\
\hline Convenience & 0.609 & 0.232 \\
\hline Customer Switching intentions & 0.552 & 0.321 \\
\hline
\end{tabular}

\section{Findings of Reliability}

In this study, Cronbach alpha scale was applied in measuring the internal consistency of respondents across a set of questions. The findings of the study indicated that the variables of the study had Cronbach's Alpha Coefficient ranging from 0.703 to 0.782 . This implies that the scale had high internal data consistency. According to the rule of the thumb, a study with a coefficient of 0.7 or above tends to have high internal consistency and vice versa (Hatcher, 1994 and Santos, 1999). Table3 presents the findings of reliability statistics.

Table 3

Reliability Statistics

\begin{tabular}{l|c|c}
\hline & Cronbach's Alpha & N of Items \\
\hline Perceived control of bank charges & 0.782 & 5 \\
\hline Attitude toward service quality & 0.703 & 6 \\
\hline Subjective norms & 0.732 & 5 \\
\hline Convenience & 0.712 & 5 \\
\hline Customer switching intentions & 0.746 & 2 \\
\hline
\end{tabular}

\section{Respondents' Demographic Information}

Under this section, the respondents were asked to provide information relating to their gender, academic qualifications, affiliate banks as well as whether they have ever shifted from one bank to another bank. It was established that 215 (53.75\%) of the total respondents were males while 185 (46.25\%) were females. These findings suggest that males are more involved in matters relating to financial transactions than females. This study established that $96(24.0 \%)$ of the total respondents were NBC bank customers while 212 (53.0\%) were NMB bank customers. Additionally, it was revealed 
that $92(23 \%)$ of the total respondents were TPB bank customers. This means that the respondents in the study were from the selected commercial banks involved in the study. On academic qualifications, $58(14.5 \%)$ of the total number of the respondents had 0 level and A level education; $24(6.0 \%)$ had certificate level education and it was reported that $62(15.5 \%)$ of the total number of respondents had diploma level education while 229 (57.2\%) of the total respondents were of the bachelor degree level.

It was also revealed that $26(6.5 \%)$ of the total respondents had masters degree while the least number of the total respondents which was $1(0.2 \%)$ was recorded to have $\mathrm{PhD}$ level of education. This denotes that most of the customers in commercial banks were educated people with either bachelor or diploma education levels. Additionally, it was found that the majority i.e. $216(65.0 \%)$ of the total respondents had shifted from one bank to another bank while $139(34.8 \%)$ had never shifted from one bank to another bank. These findings imply that commercial banks in Dar es Salaam city have been experiencing customer switching. Table 4 presents the findings of the respondents' demographic information.

Table 4

Respondents' Personal Information

\begin{tabular}{l|l|c|c}
\hline \multicolumn{1}{c|}{ Demographic Variables } & Characteristics & Frequency & \% \\
\hline \multirow{2}{*}{ Gender } & Male & 215 & 53.75 \\
\cline { 2 - 4 } & Female & 185 & 46.25 \\
\hline \multirow{2}{*}{ Respondents' distribution by bank } & NBC Bank LTD & 96 & 24.0 \\
\cline { 2 - 4 } & NMB Bank PLC & 212 & 53.0 \\
\cline { 2 - 4 } & TPB Bank & 92 & 23.0 \\
\hline \multirow{2}{*}{ Academic qualifications } & O level & 38 & 9.5 \\
\cline { 2 - 4 } & A level & 20 & 5.0 \\
\cline { 2 - 4 } & Certificate & 24 & 6.0 \\
\cline { 2 - 4 } & Diploma & 62 & 15.5 \\
\cline { 2 - 4 } & Bachelor & 229 & 57.2 \\
\cline { 2 - 4 } & Master & 26 & 6.5 \\
\cline { 2 - 4 } & PhD degree & 1 & 65.2 \\
\cline { 2 - 4 } & Yes & 261 & 34.8 \\
\cline { 2 - 4 } & Nhether a respondent has ever & 139 & \\
\hline
\end{tabular}

\section{Results of Model fit Statistics}

The goodness of fit of independent variables on predicting the changes on dependent variable was determined by using multiple coefficients of the regression model. The findings of the study indicated that the values of $\mathrm{R}$ was 0.980 (98\%), R-squared $\left(R^{2}\right)$ was $0.960(96 \%)$ and adjusted $\mathrm{R}$ square $\left(R^{2}\right)$ was 0.960 (96\%). Because this was a multiple regression model, the adjusted $R^{2}$ statistics was employed to measure how good predictors fit in the multiple regression equation. Therefore, based on the findings of Adjusted $R^{2}$ statistics, it can be pointed out that $96 \%$ of the variations on the dependent variable were explained by the independent variables used in the regression model, while $4 \%$ of the variations were explained by other factors outside the model.

This implies that perceived control of bank charges, attitude toward service quality and convenience were good predictors of customer switching intentions in commercial banks of Tanzania. In the same line, Pirzad et al (2014) established the $R^{2}$ square of $52 \%$ when explaing factors influencing customer switching behaviour in banking sector of Pakistan. Additionally, the $R^{2}$ of $81 \%$ was noted by Agarwal (2019) when addressing customer switching behaviour in Indian banking industry. These findings imply that regression is a good model in assessing customer switching intentions/behaviour in the banking business. The findings of the model summary for factors influencing customer switching intentions in commercial banks are presented in Table 5. 
Table 5

Model Summary of Findings of Goodness of Fit Test for Customer Switching intentions

\begin{tabular}{c|c|c|c|c}
\hline Model & R & R Square & Adjusted R Square & Std. Error of the Estimate \\
\hline 1 & $0.980^{\mathrm{a}}$ & 0.960 & 0.960 & 0.06006 \\
\hline
\end{tabular}

a. Predictors: (Constant), Convenience, P. Control of Bank Charges, S.Norms,

A. Service Quality

\section{Research Hypotheses Testing}

This section presents the findings of the hypotheses test. By using multiple regression analysis, the hypothesised relationships were examined against regression coefficients $(\beta)$ and $P$ values. Results suggest that perceived control of bank charges have a positive and significant influence on customer switching intentions in commercial banks with regression coefficient values of 0.649 and $P$-values of 0.024. This implies that perceived control of bank charges are statistically significant at $5 \%$ significant level and more likely to influence customer switching intentions in commercial banks, thereby supporting the first hypothesis $\left(H_{1}\right)$ of the study, that perceived control of bank charges have significant influence on customer switching intentions in commercial banks.

Also, this study pointed out that attitude toward service quality has significant influence on customer switching intentions in commercial banks. The regression coefficient indicated the values of -0.507 and $P$-values of 0.000 . These results mean that attitude toward service quality has negative and significant influence on customer switching intentions in commercial banks. Based on these findings, it can be stated that the second hypothesis $\left(\mathrm{H}_{2}\right)$ of this study is supported, and therefore attitude toward service quality has significant influence on customer switching intentions in commercial banks.

Further, this study proposed that subjective norms have significant influence on customer switching intentions in commercial banks. The regression results revealed the coefficient values of 0.160 and $P$-values of 0.549 . These findings imply that subjective norms are insignificant. Thus, the third hypothesis $\left(\mathrm{H}_{3}\right)$ is not supported; in saying subjective norms will not predict customer switching intentions in commercial banks.

Lastly, this study propounded that convenience has significant influence on customer switching intentions in commercial banks. The findings of regression results indicated the coefficient values of -0.451 and P-values of 0.021 . These findings imply that the fourth hypothesis $\left(H_{4}\right)$ of the study is supported, that convenience has significant influence on customer switching intentions in commercial banks. The findings of hypotheses testing are presented in Table 6.

Table 6

Results of Hypotheses Testing

\begin{tabular}{l|c|c|c|c|c}
\multicolumn{1}{c|}{ Hypotheses } & $\begin{array}{c}\text { B } \\
\text { Coefficients }\end{array}$ & S. E & $\boldsymbol{t}$ & Sig. & Results \\
\hline $\begin{array}{l}\boldsymbol{H}_{1} \text { : Perceived control of bank charges have } \\
\text { significant influence on customer switching } \\
\text { intentions in commercial banks }\end{array}$ & 0.649 & 0.125 & 1.993 & 0.024 & Supported \\
\hline $\begin{array}{l}\boldsymbol{H}_{2:} \text { Attitude toward service quality has significant } \\
\text { influence on customer switching intentions in } \\
\text { commercial banks }\end{array}$ & -0.507 & 0.129 & -3.941 & 0.000 & Supported \\
\hline $\begin{array}{l}\boldsymbol{H}_{3} \text { : Subjective norms have significant influence on } \\
\text { customer switching intentions in commercial } \\
\text { banks }\end{array}$ & -0.160 & 0.144 & -1.108 & 0.549 & $\begin{array}{c}\text { Not } \\
\text { Supported }\end{array}$ \\
\hline $\begin{array}{l}\boldsymbol{H}_{4} \text { : Convenience has significant influence on } \\
\text { customer switching intentions in commercial } \\
\text { banks }\end{array}$ & -0.451 & 0.131 & -0.603 & 0.021 & Supported \\
\hline
\end{tabular}




\section{DISCUSSION OF THE FINDINGS}

This research examined the influence of perceived control of bank charges on customer switching intentions in commercial banks. The hypothesis testing revealed that perceived control of bank charges had a significant positive influence on customer switching intentions in commercial banks. This means that when bank charges are increasing, they are most likely to stimulate customers' intention to switch from one bank to another. These results suggest that commercial banks must be careful in setting service charges as the pertaining increases will lead to customer switching out. Also, the results suggest that perceived control of bank charges are the strongest factor among the four factors in influencing customer switching intentions. This shows how much customers are more concerned with various charges associated with banking services. The results of this study are consistent with the findings by Sharmin (2017), Keaveney (1995), Chukwuemeka and Godswill (2017), Olsson and Gall (2012), Ceesay (2017), Zakiy (2019) and Agarwal (2019). On the contrary, Clemes et al (2008) and Misbah (2014) discovered that price had no significant relationship with customer switching behaviour in the banking industry of New Zealand and UK respectively. The disparate of the findings are an indication that banking customers in different countries are likely to respond differently to increases in bank charges for their services.

Also, multiple regression analysis reveals that attitude toward service quality had a negative and significant influence on customer switching intentions in commercial banks. This means that when services offered are of low quality, they may result in a likelihood of customer switching from one bank to another bank. Therefore, poor service quality in a commercial bank is regarded as a catalyst for customer switching out in search for the best service quality alternatives. Results of this study suggest consistent improvement of service quality so as to retain existing customers. The research findings of this study are in line with the study by Mahapatra and Kumar (2017), Ceesay (2017) and Elliot (2019). Inconsistently, Kura et al. (2012) and Misbah (2014) found out that service quality had no significant effect on customer switching in the banking industry. However, the variation of these findings is a notification that what matters to the customers in a certain market is not necessarily expected to be the same in other marketing contexts. Thus, it is an obligation of commercial banks to study their customers thoroughly so as to serve them accordingly for effective retention.

Furthermore, it was indicated that subjective norms had no significant influence on customer switching intentions in commercial banks. These findings suggest that commercial banks customers in Dar es Salaam city are not under robust social pressure that requires a vital social group to approve their switching intentions. Similar results were noted by Bansal and Taylor (2002). On the contrary, Gall and Olsson (2012), Tai and Chuang (2016), Farah (2017) and Sivakumaran and Peter (2020) pointed out that subjective norms were significantly correlated with customer switching intentions in the banking industry. The variation of these findings infers that customers across the globe have different perceptions and beliefs about services offered. Accordingly, their perceptions and beliefs are likely to influence their switching intentions from a service provider significantly or insignificantly.

Additionally, the findings of this study found a negative and significant influence of convenience on customer switching intentions in commercial banks. Thus, the more convenient the service delivery in commercial banks, the lower the customer switching intentions. This is because convenience is one of the important aspects to attain customer loyalty in a business firm. The findings of this study corresponded with those of Gerrard and Cunningham (2004), Nyarko (2015), Nimako (2012), (WRBR, 2018) and Bugyei(2019). Dissimilarly, Treasury (2010) found out that convenience was not a factor influencing customer switching in Australia banking business.

\section{Implications of the Study}

This study added a variable of convenience to the theory of TPB, which was borrowed from the Service Switching Model, advanced by Keaveney (1995). The added variable was found to be statistically significant with a negative influence on customer bank switching in the banks under study with $\beta$ of -0.451 and P-values of 0.021 . This forms one of the significant theoretical contributions of this study. Furthermore, the research findings reveal a significant contribution of the theory whereby, 
two variables of the theory; perceived behaviour control (perceived control of bank charges) and individual attitude (attitude toward service quality) were statistically significant on customer switching intentions in the commercial banks. On the contrary, subjective norms were seen to be insignificant and had a negative influence on customer switching intentions in commercial banks. This infers that subjective norms were not an important variable in assessing customer switching intentions in commercial banks of Tanzania.

Accordingly, it can be concluded that the applicability of TPB in studying customer switching intentions in banking industry differ in various marketing environments. Practically, the study established that perceived control of bank charges significantly and positively influence customer switching intentions in commercial banks. That means customers are likely to switch between commercial banks because of high charges demanded by the banks. Such observations are an alert to bank managers to conduct a thorough survey of comparable charges in other banks before setting their levels of service charges on customers.

Consistently, attitude toward service quality and convenience ware established to be the variables influencing customer switching intentions between commercial banks. Managers of commercial banks should therefore be more focused on improving service quality and convenient environments for their customers so as to address and possibly control customer bank switching intentions. Also, this study calls for the policymakers and, in this case, the BoT which is a regulator of all financial institutions to strengthen policy related to bank charges, convenience and service quality in order to control customer switching intentions and foster stability, efficiency and effectiveness of commercial banks.

\section{Limitations of the Study and Areas for further Studies}

This study focused more on commercial banks of Dar es Salaam. Yet it is clear that there exists non-commercial banks and these were not addressed in this study. Thus, future studies should focus beyond commercial banks in an attempt to assess the factors influencing customer tendencies to change banks from which they get banking services. Accordingly, this study addresses switching intentions in the banking industry. Thus, there is room for future researchers to assess factors influencing customer tendencies and behaviours to switch from one service provider to another such as service providers in hotels, and hands-on- employers such as in manufacturing. Additionally, the variable of subjective norms was found to be insignificant in examining customer switching intentions in commercial banks. Thus, further studies should test its effect on customer switching intentions in other industries such as manufacturing and tourism.

\section{References}

Agarwal, K. P. (2019). Drivers of bank/branch switching international behaviour in retail banking: Evidence from the Indian banking customers. Journal of Marketing and Consumer Research, 54, 1-12.

Ajzen, I. (1991). The Theory of Planned Behaviour. Organizational Behaviour and Human Decision Process, 50(2), 179-211

Ally, Z. (2013). Efficiency analysis of commercial banks in Tanzania. European Journal of Business and Management, 5(31), 193-203.

Anton, C., Camerero, C., \& Carrero, M. (2007). Analyzing the firm's failure as determinants of customer switching intentions. European Journal of Marketing, 41(2),135-158.

Bank of Tanzania (BoT, 2019). Annual Report 2018/2019, Dar es Salaam-Tanzania.

Bansal, H. S., \& Taylor, S. F. (2002). Investigating interactive effects in the theory of planned behaviour in a service provider switching context. Journal of psychology and marketing, 19(5), 407-425.

Bansal, H. S., \& Taylor, F. S. (1999). The Service Provider Switching Model (SPSM): A model of consumer switching behaviour in the service industry. Journal of Service Research, 2(2), 200218 
Bolton, R. N., \& Bronkhorst, T. M. (1995). The relationship between customer complaints and subsequent exit behaviour: Association for Consumer Research (ACR) North American Advances.

Bugyei, G. (2019). Customers' switching behaviour in the banking industry in Cape Coast Metropolis, Ghana. Journal of Marketing and Consumer Research, 61(1), 1-8.

Business Systems Group (BSG, 2017). Understanding customer switching behaviour in the banking environment to actively drive growth. Available on reserved.za/wpcontent/uploads/2019/01/understanding-customer-switching-behaviour-in-the-bankingenvironment.pdf.Retrieved on October 25, 2020, at 6.13 PM.

Caruana, A. (2004). The impact of switching costs on customer loyalty: A study among corporate customers of the mobile telephone. Journal of Targeting, Measurement and Analysis for Marketing, 12(3), 256-268.

Ceesay, B. L. (2017). Consumer-band association: Determinants of consumer bank switching intention, Case of the Gambia retail banking sector. Journal of Business and Financial Affairs, 6(4), 2-8.

Chukwuemeka, O., \& Godswill, A. (2017). Drivers of customers switching behaviour in Nigeria banking industry. International Journal of Management and Commerce Innovations, 4(2), 932- 943.

Chung, J. Y., \& Petrick, J.F. (2015). Measuring price fairness: Development of a multidimensional Scale. Journal of Travel \& Tourism Marketing, 32, 907-922.

Churchill, G. (1979). A paradigm for developing a better measure of marketing constructs. Journal of Marketing, 16(1),64-73.

Clemes, M. D., Gan, C., \& Zhang, D. (2010). Customer switching behaviour in the Chinese retail Banking Industry. International Journal of Bank Marketing, 28(7), 519-549

Deloitte access economics. (2019). Choice in banking. Australian Banking Association.

Elliot, S. (2019). Open banking: Switch or stick? Insights into customer switching behaviour and trust. Australia and New Zealand banking group.

Ernst \& Young. (2012). Global consumer banking survey. Retrieved from https://www.ey/com/za/en/newsroom/newsrelease/2012: Accessed on 10 ${ }^{\text {th }}$ December, 2018 at $2.23 \mathrm{PM}$.

Ernst \& Young. (2011). A new era of customer expectation: Global consumer banking survey. Retrieved on 20th March 2020 from; htps://www.ey.com/Publication/vwLUAssets/ey-a-newera-of-customer-expectation-global-consumer-banking-survey.

Farah, F. M. (2017). Application of the theory of planned behaviour to customer switching intention in the context of bank consolidations. International Journal Bank Marketing, 35(1), 147-170.

Fornell, C., \& Larcker, D. (1981). Evaluating structural equation models with unobservable variables and measurement error. Journal of Marketing Research, 18(1)39-50.

Gerrard, P., \& Cunningham, J, B. (2004). Consumer switching in the Asian market. Journal of Service Marketing, 18(3), 215- 223.

Gronross, C. (1982). An Applied Service Marketing Theory. European Journal of Marketing, 16, 30-41.

Hair, J. F., Black, W. C., Babin, B. J. \& Anderson, R. E. (2010). Multivariate data analysis: Global perspective (7th Ed), Pearson.

Hasbullah, N., Mahajar, J. A., \& Salleh, I. M. (2014). The conceptual framework for predicting loyalty intention in the consumer cooperative by using the modified theory of planned behaviour. International Journal of Business and Social Science, 5(11), 209-213.

Hatcher, L. (1994).A step by step approach to using the SAS(R) System for analysis and structural equation modelling. Cary, NC: SAS Institute.

Keaveney, S. M. (1995). Customer switching behaviour in service industries: An exploratory study. Journal of Marketing, 59(2), 71-82.

Lee, R., Murphy, J., \& Swilley, E. (2007). The Moderating Influence of Hedonic Consumption. Paper Presented at the AMA Summer Educator's Conference, Washington, DC.

Mahapatra, S. N., \& Kumar, P. (2017). Reasons why the customer dissolves their banking relationship from existing banks. International Journal of Research, 5(6), 261-271.

Millas, A. (2013). The link between service quality and customer satisfaction in the retail banking in Tanzania: A case of CRDB Bank: A dissertation submitted in partial fulfilment of the 
requirement for the degree of Master of Business Administration of the Open University of Tanzania. University of Umea, Sweden, BA- publications.

Misbah, H. (2014). Customer switching: An exploratory study of predictive factors in the UK retail banking context. A thesis submitted in fulfillment of the requirements for the Degree of Doctor of Philosophy, the University of Edinburgh.

Mkoma, M. H. (2014). Customers' satisfaction with banking services a case of Standard Chartered Bank. A dissertation submitted in partial fulfilment of requirements for the degree of Master of Business Administration of the Open University of Tanzania.

Morgan, S. M., \& Dev, S. C. (1994). An empirical study of brand switching for retail service, Journal of Retailing, 70(3), 267-282.

Munatsi, M., \& Zhuwau, R. (2019). Business survival during turbulent economic situations. Lessons from Zimbabwe. International Journal of Business, Economics and Social Studies, 3(1), 23-31.

Murungu, F. (2013).Customers' switching behaviour on banking performance, a case of NBC Ltd. International Journal of Scientific and Research Publications, 5(7), 1-96.

Murad, M. M. M. (2011).Direct and moderating factors affecting customer switching intention. An empirical study on the bank of Palestine and Cairo Amman banking in Gaza. The Islamic University - Gaza

National Microfinance Bank PLC (NMB) Annual Report, 2015.

National Microfinance Bank PLC (NMB) Annual Report, 2017.

Nimako, S. (2012). Consumer switching behaviour: A theoretical review and research agenda. Journal of Social Science and Management, 2(3), 74-82.

Nyarko, K. I. (2015).Evaluation of factors influencing switching behaviour by Ghana commercial bank, limited in Ho. British Journal of Marketing Studies, 8, 35-46

Olsson, F., \& Gall, G. (2012). How do the predictors of switching intention influence switching behaviour? A quantitative study of students' switching behaviour in the retail banking context, Umea School of Business and Economics.

Pande, C. A., \& Soodan, V. (2015). The role of consumer attitude, beliefs and subjective norms as predictors of purchase behaviour: A study on personal care purchases. The Business and Management Review, 5(4), 284- 291.

Parasuraman, A., Zeithaml, V. A., \& Berry, L. L. (1988). SERVQUAL: A multiple-item scale for measuring consumer perceptions of service quality. Journal of Retailing, 64, 12-40.

Ruefenacht, M., Schlager, T., Maas, P., \& Puustinen, P. (2015). Drivers of long-term saving behaviour from the consumers' perspective. International Journal of Banking Market, 33(7), 922-943.

Santos, J. (1999). Cronbach's Alpha: A tool for assessing the reliability of scales. Journal of extension, 37(2), 1- 4.

Sivakumaran, V., \& Peter, S. (2020). Model to assess consumer switching behaviour. Proceedings of the International Conference on Industrial Engineering and Operations Management, March 10-12, 2020.

Statista.com. The annual number of customers switching their current bank account provider in the $\begin{array}{llllll}\text { United } & \text { Kingdom } & \text { (UK) } & \text { from } & 2012 & \text { to }\end{array}$ https://www.statista.com/statistics/417417/number-of-switching-current-bank-accountsannually-uk/.Retrieved on $21^{\text {st }}$ October 2020 at 11.13 AM.

Suryawardani, B., \& Wulandari, A. (2020). Determinant factors of customers switching behaviour to customer satisfaction and loyalty in online transportation users in Bandung. Jurnal Dinamika Manajemen, 11(1), 12-25.

Tai, F. Y., \& Chuang, F. Y. (2016). Customer switching behaviour in the service industry. Management Research Review, Emerald Group Publishing, 39(8), 925-939.

Taylor, S., \& Todd, P. A .(1995). Assessing IT usage: The role of prior experiences. MIS Quarterly, 19(3), 561-570.

Walker, D. J., \& Thaqafi, T. A. (2015). Future proofing bank loyalty among students: A New Zealand study. New Zealand Journal of Applied Business Research, 13(2), 51-71.

World Retail Banking Report (WRBR,2018). Retrieved on 
https://www.worldretailbakinggreport.com/wp. Accessed on October 15, 2019 at $08.30 \mathrm{AM}$ $\mathrm{Xu}, \mathrm{X} ., \mathrm{Li}, \mathrm{H} ., \mathrm{Heikkila,} \mathrm{J.,} \mathrm{\&} \mathrm{Liu,} \mathrm{Y.} \mathrm{(2013).} \mathrm{Exploring} \mathrm{individuals'} \mathrm{switching} \mathrm{behaviour:} \mathrm{An} \mathrm{empirical}$ investigation in social network games in China. In the Blede Conference, 141-153. 